\title{
Hepatocellular Carcinoma TNM Finding v8
}

National Cancer Institute

\section{Source}

National Cancer Institute. Hepatocellular Carcinoma TNM Finding v8. NCI Thesaurus.

Code C134457.

A finding about one or more characteristics of hepatocellular carcinoma, following the rules of the TNM AJCC v8 classification system. This staging system applies to hepatocellular carcinomas and fibrolamellar carcinomas (fibrolamellar variant of hepatocellular carcinoma). Intrahepatic cholangiocarcinomas, combined hepatocellularcholangiocarcinomas, and sarcomas of the liver are not staged using this staging system. (from AJCC 8th Ed.) 